\title{
Evento OU ATO? Sobre as CRÍTICAS DE ŽIŽEK A BADIOU ${ }^{1}$
}

Mariana Pimentel Fischer ${ }^{2}$

\begin{abstract}
Resumo: $\mathrm{O}$ artigo examina o conceito de Evento elaborado por Alain Badiou e o contrapóe à noção lacaniana de ato, tal como reformulada por Slavoj Žižek. Investigará, para tanto, alguns dos trabalhos centrais em que o filósofo francês reconstrói ideias de Lacan, a partir de engenhosas associaçóes com Espinosa, Ésquilo e textos militantes de Marx. Badiou escreve sobre uma ruptura não dialética entre Ser e Evento. Žižek, mais fiel a Lacan e também a Hegel, defende a existência de uma unidade entre as dimensóes separadas por Badiou. De acordo com o esloveno, um ato político não estabelece, de pronto, um engajamento em um novo começo. Ele apenas limpa o caminho para isso. Dizer "não" eria, entâo, suficiente para a realização de um verdadeiro ato revolucionário?
\end{abstract}

Palavras-chave: Evento. Ato. Revoluções. Psicanálise.

\section{INTRODUÇÁO}

Como acontecem as verdadeiras revoluçôes? Eis uma pergunta que precisa ser feita no tempo atual, após o avanço da ultradireita no Ocidente (e daquilo que alguns chamam de revolução conservadora), seguido pela pandemia de Covid-19. Os filósofos, hoje, não cansam de questionar o papel do vírus e de seu modo de embaralhar tendências que haviam sido anteriormente diagnosticadas. O mundo pós-pandemia acentuará certos aspectos, como a vigilância e o controle já presentes na forma atual do capitalismo ou vivenciaremos uma ruptura profunda com o nosso modo de vida?

\footnotetext{
${ }^{1}$ Agradeço aos comentários de Vladimir Safatle e dos integrantes do LATESFIP/USP, sem os quais este artigo não poderia ter sido elaborado.

2 Professora da Universidade Federal de Pernambuco (UFPE), Recife, PE - Brasil. (D) https://orcid. org/0000-0003-3217-5756. Email: marianafisch@gmail.com.
}

https://doi.org/10.1590/0101-3173.2021.v44n3.25.p317 
Badiou e Žižek fornecem respostas muito diferentes a essas questôes. O filósofo francês escreve sobre a "[...] ausência de novidade da atual situação epidêmica” (BADIOU et al., 2020, p. 70) e menciona com ironia aqueles que, como Žižek, olham para o vírus e "[...] clamam por um evento fundador de uma revolução sem precedentes.” (BADIOU et al., 2020, p. 70). Já o esloveno, em um tom supreendentemente sério e otimista, sugere que a pandemia pode dar um novo impulso à vida do comunismo. Tal divergência marca, de maneira muito clara, as diferenças entre dois pensadores que, durante todo seu percurso intelectual, não cessaram de perguntar pela possibilidade de insurgência de algo radicalmente novo. Que pressupostos estariam, então, por trás desses desacordos?

As ideias de Žižek e Badiou emergem de uma matriz comum, partindo de articulaçóes entre Marx e Lacan. Em razáo de seguirem esse caminho, são capazes de ir além de teorias pluralistas assentadas na incomensurabilidade de discursos (como algumas perspectivas pós-modernas, que dificultam um engajamento político ${ }^{3}$ ), assim como de uma filosofia política centrada no consenso (como quer Habermas). Eles pretendem justamente cuidar dos efeitos daquilo que não pode ser absorvido pelo discurso (BADIOU, 1999). É, de fato, justamente a preocupação com operaçôes (militantes ou clínicas) inassimiláveis pela linguagem o que aproxima perspectivas marxianas e a lacaniana.

Pensar transformaçôes sociais a partir de Žižek e Badiou exige refletir sobre a possibilidade de ultrapassar alternativas que nossa vida social apresenta como viáveis, porque as ideias de ambos estão centradas na força destituidora do não esquematizável Real lacaniano. ${ }^{4}$ Os dois filósofos sabem que aquilo que não pode ser simbolizado tem efeitos e sabem também que esses efeitos podem ser produtivos. A tarefa é, portanto, para ambos, encontrar uma maneira adequada de lidar com o potencial político de um resto inassimilável.

Investigarei, portanto, as diferentes maneiras pelas quais Žižek e Badiou pensam a relação entre o Real e as revoluçóes. Pretendo me concentrar em um ponto específico do debate: o conceito de Evento formulado por Badiou (leitor crítico de Lacan) e as objeçôes de Žižek (mais fiel ao psicanalista),

3 "Lacan também, em oposição ao pós-modernismo, está correto: ciência não é apenas um mero jogo de linguagem; ela se relacional com o não esquematizável Real.” (BADIOU; ŽIŽEK, 2009, p 57).

${ }^{4}$ No Seminário XI, Lacan (1988, p 159) oferece uma importante chave de leitura, ao associar o Real ao impossível: "O real se distingue, como eu disse da última vez, por sua separação do campo do princípio do prazer, por sua dessexualização, pelo fato de que sua economia, em seguida, admite algo de novo, que é justamente o impossível." 
as quais estão associadas à sua perspectiva sobre o ato. Badiou se afasta da psicanálise lacaniana, ao defender a separação radical entre duas dimensóes: de um lado, o Ser e, de outro, o Evento. No campo do Ser, não há lugar para o sujeito: este último é constituído pelos efeitos do Evento. Žižek defende a existência de uma unidade entre as dimensóes separadas por Badiou, já que, segundo o filósofo esloveno, "[...] o sujeito está inscrito na mesma estrutura ontológica do universo como seu vazio constitutivo." (ŽIŽEK, 2000, p. 160). Como Badiou fundamenta essa separação entre as duas dimensóes? Quais as consequências políticas de tal cisão? De que modo o lacaniano Žižek pensa a ligação entre ato psicanalítico e política e, nesses termos, responde aos desafios colocados pela teoria badiouiana?

Para examinar tais questóes, percorrerei alguns dos principais trabalhos que mostram a maneira peculiar com que Badiou lê Lacan. Em primeiro lugar, pontuarei as divergências do filósofo francês com seu professor, Louis Althusser, de maneira a apresentar sua crítica a um modelo de causalidade estrutural e indicar os recursos que Badiou utiliza, para separar os campos do Ser e do Evento. Em seguida, observarei de maneira mais detida seu modo particular de ler Lacan, na "Teoria do Sujeito", que está embasado em engenhosas associaçóes com Ésquilo (em vez de Sófocles) e textos militantes de Marx. O terceiro passo será abordar a interpretação de Badiou de São Paulo, engatando-a às críticas de Žižek, que também usa exemplos do Cristianismo (em especial, a história de Jó) para ilustrar ideias de Lacan. Por fim, investigarei a perspectiva de Žižek sobre o ato lacaniano e problematizarei a concepção de Evento defendida por Badiou.

\section{Além da causalidade estrutural de Althusser}

Desde seus trabalhos iniciais, Badiou busca superar deficiências que identificara na forma de associar Marx e Lacan, defendida por seu professor, Louis Althusser. A base do problema estaria em um modelo de causalidade estrutural que teria impedido Althusser de separar adequadamente ciência e ideologia. Badiou realiza uma reversão em tal oposição, por meio de formulação de um novo par: conhecimento e verdade. A primeira díade não seria autêntica. Cega para o vazio, permaneceria confinada à ordem positiva do Ser. Reside no segundo par a abertura para a verdade, que engaja, subjetiviza e produz uma perspectiva autêntica para a situação. 
De fato, é o ponto de vista do sujeito militante que realmente interessa ao filósofo, e é justamente esse aspecto do marxismo que busca retomar. Ele rejeita a noção de ciência da história da crítica de Marx à economia política e defende uma definição militante das referências a textos de Marx, Lenin e Mao, em experimentos políticos concretos. Afirma: "[...] não podemos repetir suficientemente que os textos do marxismo são primeiro e acima de tudo aqueles da política militante" (BADIOU, 1982, p. 296); assim “[...] o marxismo, incorporado a partir de qualquer ponto que não seja a sua efetiva operação que é inteiramente da ordem da política de dentro das massas, não merece uma hora de nossa atenção." (BADIOU, 1992, p. 146).

A perspectiva engajada marxiana é reconstruída por Badiou, por meio de sua costura a uma teoria do sujeito de inspiração lacaniana. O marxismo apenas pode ser liberado de suas fixaçóes, se abandonar a suposição de que a ciência da história deve dar conta de fatos sociais empíricos; em vez disso, a compreensão da história precisa ser entendida como resultado retroativo da política, a partir do ponto de vista de um sujeito constituído pelos efeitos do Evento. É, portanto, uma teoria do sujeito que poderá dar lugar à lógica de tais intervençōes retroativas (BADIOU, 1982; BOSTEELS, 2009).

Para apresentar o projeto que somente esbocei até agora, importa recordar que, no texto "Louis Althusser: O (Re)começo do Materialismo Histórico”, publicado ainda em 1967, Badiou (2012) faz breves mençóes a Lacan e escreve sobre suturar lacunas no texto de Althusser. Alude, assim, a "A Sutura", de Jacques-Alain Miller (orientador de Žižek, em seu segundo doutorado), sem se vincular a esse trabalho.

Para Miller (1966), sutura é a operação por meio da qual aquilo que é faltante passa a contar como elemento de um conjunto, tal como na operação do sucessor de Frege, em que n', sucessor de 1, é igual a “n + 1". Nesse sentido, após passar pela operação do sucessor $(0+1)$, o 0 torna-se 1 . 0 conta como 1: esse é o fundamento geral da série dos números. De acordo com Miller, 0 indica a falta (isto é, o sujeito) que, após a referida operação, passa a ser representada por 1. Este último (o número 1) é o nome próprio de um número, daquele que chega a fixar um traço de 0 (do sujeito não idêntico) suturado pela identidade consigo mesmo. O paradoxo é: o traço do idêntico representa o não idêntico. $\mathrm{A}$ sutura pode, então, ser compreendida como a relação da falta com a estrutura ou do sujeito com a cadeia de seu discurso, em que aquele figura como o elemento que falta sob a forma de algo que toma o seu lugar. É nesse sentido que, faltando, ele não está puramente ausente. 
A dialética entre vazio e excesso (ou 0 e 1, nos termos de Miller) é crucial para Badiou. Contudo, a concepção lacaniana, herdada por Miller e Althusser, a qual pensa o sujeito como 0 ou vazio suturado é problematizada, pois teria criado um impasse e impossibilitado que Althusser realizasse uma crítica à ideologia, sem ser capturado pela própria ideologia.

Para superar esse problema, Badiou recorre à matemática e à noção de multiplicidades puras que precederiam a constituição de estruturas e, portanto, não estariam determinadas por estas últimas. Rompe com a tradição lacaniana e althusseriana, ao deslocar o sujeito, o qual não é mais compreendido como um ponto vazio (“0”) inscrito em uma estrutura. O sujeito, em Badiou, extravasa a estrutura (ou, como veremos, o campo do Ser), já que é raro e está ligado ao Evento.

A questão é desenvolvida por Badiou, de maneira sistemática, em Ser e Evento (1988), cerca de duas décadas depois da publicação de "O (Re) começo do Materialismo Histórico". A partir da teoria dos conjuntos de Cantor e da ideia de que múltiplos sáo compostos por múltiplos, o filósofo escreve sobre o Ser, que "[...] não seria outra coisa senão multiplicidade pura" (BADIOU, 1988, p. xiii), e a ontologia, portanto, "[...] não é outra coisa senão a matemática ela mesma." (BADIOU, 1988, p. xiii).

Se múltiplos são compostos por múltiplos, não há uma unidade originária. Há, contudo, estrutura, pois em cada situação há uma regra que permite contar o inconsistente múltiplo. Os objetos individualizados do mundo nos são apresentados com base em tal regra, e o Ser é o nome do que nela náo se encaixa (os infinitos múltiplos de Cantor ou, se preferirmos, o vazio que antecede a simbolização). ${ }^{5}$

A partir do ponto de vista do que Badiou chama de estado de uma situação, o múltiplo precedente pode apenas aparecer como nada. Insisto que nada, aqui, é o nome do Ser (anterior à simbolização ou a contagem por Um) e não o nome do sujeito, como dizia o professor de Žižek, Jacques-Alain Miller. Na situação, o vazio é contado como algo a mais, como Um, isto é, como excesso.

A dialética entre excesso e vazio se revela de duas formas. De um lado, cada estado de uma situação (Badiou joga com o duplo sentido do vocábulo "estado", como estado de coisas e como Estado, no sentido político) envolve

5 Nesse sentido, Badiou alude a uma "ontologia subtrativa": Ser é aquilo que se subtrai a toda presentificação (BADIOU, 1988). 
um elemento excessivo, que, apesar de pertencer à situação, não é contado. Esse elemento é apresentado, mas não é representado. Žižek (2000) explica o argumento de seu amigo francês, com um exemplo esclarecedor. Uma família é um múltiplo apresentado em uma situação social e, se todos os membros forem cidadãos de um Estado e possuírem registro, será também um múltiplo representado. Se, entretanto, um dos membros da família não é registrado civilmente (um estrangeiro que está ilegalmente no país), pode-se dizer que, apesar de ser apresentado, não é representado. De outro lado, há o excesso da representação sobre a apresentação: o poder estatal, por exemplo, é necessariamente excessivo: ele jamais poderá representar plenamente a sociedade, será constituído por algum modo de intervenção que oprime aquilo que tem a pretensão de representar.

Como frisei, Badiou tenta superar Althusser, por meio de uma reversão: o par ciência/ideologia é substituído por conhecimento/verdade, e essa nova díade somente pode ser costurada por outra teoria do sujeito.

O conhecimento se refere a unidades estabelecidas com base em uma regra de contagem. Assemelha-se ao saber produzido pelas ciências positivas, que somente pode perceber uma situação como uma soma de fatores determináveis. Por exemplo, o conhecimento tradicional da história permite elencar elementos presentes na França entre 1789 e 1794, tais como jacobinos, guilhotina, alto preço da subsistência e massacres. É possível, assim, inventariar os elementos da situação e descrevê-la como um número infinito de coisas, gestos e palavras. Nessa chave, não há percepção dos excessos, problemas são percebidos como defeitos de funcionamento ou erros contingentes.

Em uma situação, contudo, há sempre algo que escapa ao conhecimento. O Evento conecta-se justamente ao que não se encaixa, ao vazio: não ao conhecimento, mas à verdade da situação. A verdade revela que aquilo que o conhecimento percebera como obstáculo empírico é, de fato, um excesso ou um sintoma (refere-se a limitaçóes transcendentais e não empíricas). Elementos conhecíveis como jacobinos, guilhotina e bastilha seriam insuficientes para provocar a Revolução Francesa; a verdade expóe que esse Evento foi impulsionado por aquilo que o estado da situação havia recalcado.

Badiou (1995, p. 72) estabelece ainda um critério para distinguir o Evento e seu simulacro: esse último estaria ligado à "[...] convocação não do vazio, mas de uma particularidade plenificada de uma situação.” A 
ascensão no nazismo na Alemanha, por exemplo, foi um pseudoevento, já que foi impulsionado pela absolutizaçáo de um dos elementos particulares da situação: os nazistas pretendiam levar uma comunidade particular (a raça ariana) à dominação universal.

Além da Revolução Francesa, exemplos de Eventos recorrentemente utilizados por Badiou são a revolução bolchevique, o Cristianismo de São Paulo, trabalhos de artistas ou cientistas que romperam com uma tradição e relaçóes amorosas que transformaram profundamente a vida dos apaixonados.

\section{O SUjeIto de BADIOU}

Se olharmos para uma situaçáo a partir do ponto de vista do conhecimento, não seremos capazes de reconhecer um Evento. Apenas uma intervenção interpretativa de um sujeito constituído pelos efeitos do Evento pode, retroativamente, estabelecer a linguagem adequada para tratar sobre sua ocorrência. Isso quer dizer que o Evento pode apenas ser identificado em função de uma posição subjetivamente engajada: somente pode ser percebido por aqueles que, tocados pelo Evento, aceitam a aposta de que ele existiu. Portanto, para Badiou (1988, p 431), sujeito é aquele que é capaz de olhar para trás e nomear o novo começo: "São Paulo para a Igreja, Lenin para o Partido, Cantor para a ontologia, Schoenberg para a música, mas também Simon, Bernard ou Claire, se eles se declaram apaixonados."

Por exemplo, o Evento fundador do Cristianismo é a Ressurreição de Cristo. Do ponto de vista do conhecimento daqueles que pertenciam ao estado da situação (anterior ao evento) teria somente ocorrido a morte de um ser humano como tantos outros. Somente os sujeitos crentes (militantes, como indicam os textos políticos de Marx), que intervêm na situação e identificam os efeitos do Evento, percebem os sinais de que uma transformação profunda teria acontecido. É nesse sentido que, para Badiou, o sujeito serve à verdade que o transcende. Sujeito é, por conseguinte, "[...] uma fidelidade ativa ao evento da verdade. Isso quer dizer que um sujeito é um militante da verdade." (BADIOU, 1988, p. 25).

O sujeito nunca está, contudo, completamente adequado à infinita ordem da verdade, pois opera dentro de um múltiplo finito de uma situaçáo (mesmo que seja uma situação nova, ou seja, inaugurada pelo Evento). Subjetivação é a configuração singular (ou uma emergência finita e contingente) 
de uma regra. Sujeito e verdade estão profundamente interligados: a teoria do sujeito, em Badiou, é uma perspectiva acerca da emergência de uma verdade universalizável. Para compreender tal interligação, importa examinar de maneira mais detida como tal ponto de vista bastante peculiar acerca do processo de subjetivação é construído, no percurso intelectual do filósofo.

Em Teoria do Sujeito, publicado em 1982, Badiou (1982, p. 46) formula, de maneira sistemática, sua reconstrução crítica de ideias de Lacan e indica o ponto de afastamento da perspectiva do psicanalista na asserção "Todo sujeito é político e, por isso, existem poucos sujeitos e raramente alguma política." Mostra, assim, que o sujeito não pode ser o zero contado como um, isto é, um elemento que, ainda que de forma paradoxal, faz parte de uma estrutura. Suas formulações iniciais são revistas em Condiçôes, onde afirma: "[...] hoje, não diria mais que todo sujeito é político [...] prefiro dizer que todo sujeito é induzido por um procedimento genérico e, portanto, depende de um Evento. Por isso, o sujeito é raro." (BADIOU, 1992, p 234). Badiou escreve, assim, sobre quatro domínios da verdade (a arte, a ciência, a política e o amor), os quais são separados e podem trazer à tona um sujeito. Em Lógica dos Mundos (2006), ele dá seguimento a tais reflexôes e investiga formas históricas de organizaçáo capazes dar corpo ao sujeito.

Mesmo após sucessivas revisóes, inegavelmente, a Teoria do Sujeito continua sendo um trabalho de fundamental importância para a compreensão do papel de Lacan em seu projeto. Interessa ao filósofo especialmente os textos tardios do psicanalista, nos quais haveria um deslocamento de ênfase: do simbólico ao Real. Badiou (1982, p. 151) escreve: "[...] no começo da década de 1970 , que marca a primazia do nó sobre a cadeia ou da consistência sobre a causalidade, é esse aspecto histórico que ganha relevância sobre o aspecto estrutural." Essa outra concepção de Real, para além de um modelo associado a uma estrutura (herdado por Althusser), carregaria a potência de ultrapassar um jogo de repetiçóes e permitiria a emergência de algo genuinamente novo.

Badiou (1982, p. 149) aponta ainda os limites que percebe, na perspectiva do psicanalista:

Toda nossa disputa com Lacan reside na divisão, que ele restringe, do processo do vazio daquele da destruiçáo. $\mathrm{O}$ Real, entấo, não volta para o mesmo lugar. Para colocar de outra maneira, aquilo que tomou lugar não é apenas o lugar ele mesmo. Em vez disso, torna-se possível que certo coeficiente ou força interrompa e retorne a trabalhar sobre o lugar que o determina, tal como a história náo se move mais automaticamente 
em círculos, mas abre uma lacuna mínima necessária para que se possa conceber um processo de periodização assimétrico e em espiral.

A força disruptiva do vazio tem, em parte, o efeito de produção de um automatismo e, de outra, a geração de uma possível interrupção (ou um excesso sobre o lugar). Badiou (1982, p 156) enfatiza que, "[...] por meio dessa lacuna, outro mestre pode vir a ser ao lado de um equilíbrio assimétrico de perda e ganho."

Como então se aproximar dessa outra concepção de Real, que, segundo o filósofo francês, Lacan parece indicar, mas não desenvolve de maneira suficiente? A resposta será dada por Badiou em Teoria do Sujeito, por meio de uma reformulação de conceitos do psicanalista fundada em Espinosa e em uma peculiar releitura da tragédia grega.

O filósofo questiona as razóes da escolha lacaniana por Sófocles e não por Ésquilo, decisão que teria dirigido a psicanálise a seguir um percurso mortífero e angustiado. Badiou (1982, p. 160) está mais interessado em Ésquilo, o qual ensinaria a coragem (em vez da prisão na angústia) e permitiria o advento contraditório da justiça: "[...] proponho que sejamos esquilianos. Lacan se posiciona ao lado de Sófocles, mas aponta para Ésquilo, que é onde quero chegar.” Ressalto que Sófocles e Ésquilo devem ser compreendidos, aqui, como conceitos operados no interior de uma reflexão filosófica e não como trabalhos literários.

No modelo trágico de Sófocles, Creonte e Antígona são figuras que realizam um mesmo processo. Creonte é o supereu, o excesso da lei que retorna ao mesmo lugar como morte. Antígona reage à lei como uma latência sem forma, é angústia ou infinitude do Real, sem um lugar possível dentro da lei do Estado (como exporemos adiante, o ato de Antígona é compreendido de maneira muito distinta por Žižek). Badiou pretende mostrar, por meio dessas figuras, que haveria um impasse radical em uma teoria que se mantém presa ao confinamento do simbólico e à noção de lugar como uma unidade. $\mathrm{O}$ sujeito seria compreendido como excrescência angustiada e nasceria da distância interna da lei consigo mesma.

De outro lado, na tragédia de Ésquilo, a dinâmica repetitiva aparece apenas como um impulso inicial. Orestes é forçado a matar sua mãe, a qual, antes disso, matara seu pai. Ele estaria, inicialmente, preso a uma série repetitiva e sem fim de assassinatos. A trilogia é orientada, todavia, pela interrupção do 
débito infinito, isto é, por uma ruptura que permitiria o advento do novo. É o decreto de Atena que produz a torção igualitária a qual abre espaço para o surgimento de um novo direito e para a recomposição da lógica da decisão. Atena é justiça e Orestes, que fora inicialmente angústia, torna-se coragem.

Diferentemente de Sófocles, em Ésquilo, as posições antagônicas não são articuladas dentro de uma mesma ordem; são, em vez disso, constituídas por uma divisão interna que está para além daquilo que tem um valor prédefinido pelo estado inicial da situação. O lugar ele mesmo, que se mostra não como um, mas como dois. Não há um retorno para a ordem originária, mas uma recomposição e a constituição de outra ordem. É por essa razão que o herói de Ésquilo não vaga no impensável: sua força consiste em se afastar de qualquer retorno ou se expor a uma reversão não nativa. É, portanto, o agente imediato do curso dinâmico da insurreiçáo.

Uma perspectiva que percebe o simbólico como indivisível não é capaz de compreender o papel do decreto de Atena. A justiça do decreto forma o ponto nodal entre lei e transformação: o princípio que sustenta a lei é abalado por um processo de cisão impulsionado por uma não lei que pode vir a funcionar como lei.

Badiou emprega outros exemplos, para demonstrar tal relação entre lei e sua ruptura. No campo das formas literárias, a poesia interrompe a prosa ordinária e, assim, expande os limites do comunicável. Na tradiçáo marxiana, a lógica do Estado é quebrada por um princípio universal de justiça, que se apresenta como revolução constituída por um sujeito partidário.

A coragem de Orestes é rebeldia contra o simbólico e, ao mesmo tempo, confiança no Real. O oposto da coragem não é o medo, mas a angústia, a qual, ao lado da morte, ocorre na medida em que se permanece preso ao jogo do simbólico. Ambas estáo conectadas a um tipo de causalidade marcada pela perda: a angústia está ligada à deficiência do lugar, enquanto a coragem assume o Real e a divisão do lugar. Esta última é mais do que somente rebeldia, exige também confiança no Real e, assim, permite que o sujeito transforme a radical ausência de qualquer segurança (dentro do campo simbólico) em sua força.

Insisto que o sujeito emerge somente por meio de uma articulaçáo entre revolta e consistência (isto é, fidelidade ao novo). Nesse ponto, Badiou não esconde a influência de Espinosa, já que, para o filósofo de Amsterdam, a segurança (compreendida como apego ao simbólico) não é uma virtude, mas um sinal de impotência do sujeito; de outro lado, a fortaleza (tal como 
a coragem de Badiou) se sustenta apenas na verdade (BADIOU, 1982; SPINOZA, 2009).

Antígona, Creonte, Orestes e Atena nomeiam o sem forma, o excesso da forma, a interrupção e a recomposição. Seriam estes os quatro conceitos que articulam sua Teoria do Sujeito, que, segundo o filósofo, Lacan já teria indicado implicitamente em 1954, ao antecipar o alcance ético da psicanálise (BADIOU, 1982; BOSTEELS, 2009).

\section{RESSURREIÇÃo OU MORTE?}

Em 1997, Badiou (1995) publica o livro São Paulo e Fundação do Universalismo, em que expóe sua perspectiva sobre o sujeito e sobre a cisão entre Ser e Evento, a partir de uma ancoragem em textos paulinos. O Paulo que o filósofo francês nos apresenta soa como Lacan, na medida em que insiste que cair nas tentaçôes da carne não significa simplesmente sucumbir às conquistas terrenas, sem respeito a proibiçôes morais da Lei: no mundo em que vivemos, não há pecado independente da Lei, pois é a proibição que faz surgir o desejo, hiperbólico e fixado no objeto proibido.

Segundo o Paulo de Badiou, a Lei divide o sujeito. Ele está cindido entre a consciência seguidora da Lei e o desejo de infringi-la; o "eu" consciente não quer violar a Lei, são impulsos (nos quais o "eu" não se reconhece) que impelem a transgressão. Separam-se o "eu" e os impulsos para o pecado, e é do lado destes últimos que está a energia vital. Assim, no mundo em que nos encontramos, nosso ímpeto vivente apenas pode se realizar em seu modo invertido, como força de transgressão que está associada a um mórbido sentimento de culpa.

Defender a purificação, por meio da expulsão de impulsos transgressores, implicaria abandonar também a nossa energia vital. Essa não pode ser, por conseguinte, a saída. Para Badiou, Paulo e também para Espinosa, a ruptura deve ocorrer por meio da afirmaçáo da vida, e é justamente nesse ponto que há um afastamento com relação à psicanálise.

Segundo Badiou, a abertura ao novo não surge da morte ou de dentro dos domínios da Lei, mas deve ocorrer em outra dimensão: um cristão age com base na atitude de zelo pela vida e pelo amor, e não em proibiçóes (a ação amorosa é, aqui, compreendida como ação fiel ao Evento). Há, desse modo, no Paulo de Badiou, duas divisôes: em primeiro lugar, a cisão entre o 
"eu" consciente e o desejo transgressor da Lei e, ainda, outra separação, mais radical, entre o domínio do Ser, que engloba a Lei e o desejo, e, de outro lado, o Evento, o qual marca o caminho do amor e de um novo começo.

Fundamental aqui é compreendermos que esse novo começo não surge apenas de uma força interna à dinâmica da situaçấo. Pressupóe exterioridade. Isso quer dizer que a relação entre as dimensôes do Ser e do Evento não é dialética. Badiou (1995, p. 77) escreve:

Eu sustentaria que a posição de Paulo é antidialética e que, para ele, a morte não é, de maneira alguma, o exercício obrigatório da potência imanente do negativo. A graça, a partir de então, não é um "momento" do Absoluto. Ela é afirmação sem negação preliminar, ela é o que nos vem na cesura da Lei. Ela é pura e simplesmente encontro.

Há uma absoluta disjunção entre a morte de Cristo e sua Ressurreição. A morte é uma operação que se dá na situação, pertence ao campo do Ser. Não é, portanto, segundo Badiou, capaz de, por si só, impulsionar a ocorrência do Evento. O novo começo evental é a Ressurreição, a qual surge fora do poder da morte (e não por sua negação). Antes da decisão (pela existência do evento), habitamos uma situaçáo fechada em seus horizontes. Dentro desse confinamento, o vazio constitutivo da situação não aparece como tal, é compreendido somente como uma perturbação marginal. O gesto que fecha/ decide a situação, então, coincide com o gesto que retroativamente a abre.

Diferentemente do filósofo francês, Žižek pretende se manter fiel a Lacan e também à dialética de Hegel. Cuida, assim, de uma subversão imanente à relação entre desejo e Lei, a qual é impulsionada pela morte. Para o esloveno, a tônica está em um gesto negativo de retirada, o qual precede qualquer gesto positivo de identificação com um novo começo (em linguagem lacaniana, com um novo significante-mestre). Importa, sobretudo, compreender o potencial produtivo da morte, que pode romper com relaçóes estabelecidas em função de valores e sentidos constituídos com base em um ponto de partida estrutural (como assinala Lacan, a partir de uma estrutura fantasmática). Mas, se não há uma dimensão exterior a Lei, como é possível realizar a travessia à qual alude Žižek? De que maneira a morte pode impulsionar movimento em vez de estagnação? 
Retomemos o exemplo do Cristianismo e insistamos na maneira pela qual Žižek (2008) associa sua leitura da psicanálise à história de Jó e a outro modo de compreender Cristo.

Jó não é um homem que suporta o sofrimento com resignação e certeza de uma posterior recompensa divina. Muito pelo contrário, ele a todo tempo se queixa de seu destino: "Depois disto, abriu Jó a boca e amaldiçoou o seu dia. E Jó, falando, disse: pereça o dia em que nasci, e a noite em que se disse: foi concebido um homem!"(Jó 3:1-3). Há aqueles que buscam convencê-lo de que existiria um sentido para o seu sofrimento, poderia estar sendo punido por seus pecados ou sua fé poderia estar sendo testada. Jó rejeita todas essas interpretações e sua resposta expressa a radical falta sentido de seu sofrimento e, por essa razão - conclui Žižek - Jó mantém sua integridade.

Segundo o filósofo esloveno, o sofrimento de Cristo é também sem sentido. A diferença é que, em Jó, há uma separação entre um ser humano que sofre e Deus, já a crucificação de Cristo aponta para uma a divisão interna, isto é, indica a existência de um Deus que se separa de si mesmo. "Pai, por que me abandonaste?" é a pergunta de um filho que uma vez acreditara no poder do Pai e que, agora, tem de lidar com a angustiante descoberta de que seu Pai não o pode ajudar. Cristo, encarnação de Deus, está diante de um Deus impotente, de um Pai morto. Žižek (2008, p. xxvi) observa: “[...] o que Deus revela não é Seu poder oculto, apenas Sua impotência como tal.”

Para o esloveno, Jó e Cristo mostram, no final das contas, que não há segredo a ser revelado. Se, em certo momento, a Lei existiu para mascarar a impotência de Deus (podemos dizer, em linguagem lacaniana, do grande Outro), a pergunta de Cristo, "Pai, por que me abandonaste?", marca a destituição de Deus de sua posição de poder. Cristo evidencia que não há poder oculto capaz de sustentar a Lei. Resta, por conseguinte, o vazio de sentido. Žižek (2008, p. 31) afirma:

Cristo não é sublime no sentido de um objeto elevado a dignidade da Coisa, ele não faz as vezes de uma impossível Coisa-Deus; ele é a Coisa ela mesma - ou, mais precisamente, a Coisa ela mesma náo é nada mais do que a ruptura/vazio que faz Cristo não completamente humano. Cristo é, portanto, o que Nietzsche, o derradeiro autoproclamado Anti-Cristo, chamou de meio-dia: a fina linha entre antes e depois, o velho e o novo, o simbólico e o Real. 
Apenas seremos capazes de nos abrirmos a algo realmente novo, se pudermos suportar a falta sentido radical ou o impasse no simbólico provocado pela força do vazio. Cristo e Jó aceitaram riscos, viveram o sofrimento e confrontaram o abandono, sem a ilusão de um sentido secreto. Essa é chave para a compreensão do ato psicanalítico, o qual não encontra amparo em uma ordem simbólica estabelecida e, por essa razão, suas consequências não podem ser calculadas previamente. $\mathrm{O}$ ato apenas se apresenta como tal depois. Em outras palavras, apenas pode ser compreendido por uma interpretaçáo constituída por seus efeitos e que retroativamente enxerga a sua realização. Como assevera Lacan, o ato ganha seu valor apenas a posteriori.

Lacan, no Seminário 15 (1967-1968, p. 63), escreve: “O ato psicanalítico designa uma forma, um envoltório, uma estrutura tal, que, de algum modo, ele suspende tudo o que até então foi instituído, formulado, produzido como estatuto do ato, à sua própria lei." O ato é, portanto, determinado por certas condiçóes e ao mesmo tempo, retroativamente, transforma as condiçóes que serviram de base para a sua realizaçáo: ele destitui, assim, o sujeito que o instaura (LACAN, 2003a, 2003b).

Em sua crítica a Badiou, Žižek (2000, p 154) insiste na importância da morte de Cristo e lembra que "[...] o nome atribuído por Freud ao vazio é pulsão de morte.” É crucial recordarmos, aqui, que Freud (2010a, 2010b) não conecta a pulsão de morte somente a morte do organismo vivo e a compulsão à repetição (aspectos que certamente poderiam estar associados ao mórbido automatismo sobre mencionado por Badiou): ele também a associa experiências inquietantes ou de estranhamento (a palavra alemã é Umheimlich) que acentuam a sua força produtiva e transformadora.

Freud fornece exemplos. Conta que, em um passeio, tentou se afastar de uma rua repleta de casas de prostituição e, sem que pudesse se dar conta, caminhou em círculos e voltou para o lugar do qual queria fugir. Menciona ainda uma mulher que, sem ter essa intenção, casou-se por três vezes seguidas com homens que rapidamente adoeciam e exigiam seus cuidados. Situações como essas ilustram a maneira pela qual algo alheio à consciência do caminhante e da mulher dirigiu suas açôes e os impulsionou a repetir padrôes dos quais queriam escapar (ou acreditavam que queriam escapar). Estranhamento se refere a experiências nas quais o sujeito se percebe como outro e pode se dar conta de que suas açóes não têm o sentido que imaginavam. Na clínica, tais vivências inquietantes abrem caminho para formas de intervenção do psicanalista (FREUD, 2010a, 2010b; LAPLANCHE, 1985). 
Lacan (2005, p. 52) conecta o estranhamento freudiano à angústia: “[...] mas se, de repente, faltar toda e qualquer norma, isto é, tanto o que constitui a anomalia quanto o que constitui a falta, se esta de repente não faltar, é nesse momento que começará a angústia.”. Angústia é aquilo aparece no lugar da falta, pois "[...] não existe imagem da falta" (LACAN, 2005, p 51), ela dissolve imagens de mundo e, assim, pode limpar o terreno para que algo genuinamente novo possa emergir. Age, portanto, como uma falha nas produçóes do grande Outro (ou na estrutura que determina a maneira pela qual compreendemos o mundo). ${ }^{6}$

\section{Consideraçótes Finais}

A morte, na crucificação de Cristo ou na pulsão freudiana, revela que há algo no sujeito que está para além do que ele representa no campo simbólico. Em linguagem lacaniana, o sujeito não se reduz à ordem do significante, há, nele, algo que insistentemente ${ }^{7}$ não se encaixa em representaçôes identitárias, algo que é do campo do Real. $\mathrm{O}$ ato funda-se justamente nessa divisão entre, de um lado, identidades intersubjetivamente estabelecidas e, de outro, aquilo que ainda não tem imagem ou o não idêntico Real. Para Lacan (2005, p 370), “[...] o ato tem lugar em um dizer e ele modifica o sujeito" e, de forma paradoxal, instaura e destitui ou, como escreve Žižek (1992, p 46), realiza uma "[...] suspensão da realidade constituída."

Conforme o esloveno, o ato tem seu impulso em um impasse. A saída žižekiana reside, portanto, lá onde Badiou enxerga apenas uma mórbida e angustiada estagnação. Para o francês, como frisado, Creonte e Antígona estão confinados em um circuito fechado. Já de acordo com o esloveno, Antígona é o grande exemplo de ruptura por meio do ato, cuja lógica está do lado feminino: a atividade masculina é uma forma de escapar do abismo que está do lado feminino, isto é, a repetição de açôes de modo compulsivo do homem é uma tentativa desesperada de fugir do vazio ou daquilo que pode genuinamente fazer o ruir o mundo que naturalizou:

Não devemos nos esquecer que o caso paradigmático de um ato é feminino: o "não" de Antígona a Creonte, ao poder do Estado; seu ato é literalmente suicida, ela se exclui da comunidade e náo oferece nada novo, nenhum programa positivo - ela apenas insiste em sua demanda incondicional.

6 Próximo a Žižek, Safatle $(2012,201)$ ressalta o papel de experiências produtivas de indeterminação.

7 Žižek (2012) é perspicaz, ao associar constantemente insistência e existência. 
Talvez devamos arriscar a hipótese de que, segundo sua lógica inerente, o ato como Real é feminino em contraste com a performance masculina, não podemos realizá-lo já que não e um processo objetivo, mas um processo continuamente interrompido pela escansáo de atos. O novo (a realidade simbólica que emerge como consequência de um ato) é sempre um estado que é essencialmente um produto, jamais um resultado de um plano anterior. (ŽIŽ̌EK, 1992, p 44-45).

A experiência-limite do ser humano é o encontro com o sem sentido; podemos apenas suportar essas experiências (como o fez Jó), pois não há como forçar uma passagem (como quer Badiou). Resta-nos a sensação de estranhamento, cuja produtividade está em seu potencial de expor a falsidade de determinado estado de coisas. Nossas tentativas de instituir uma nova ordem são ilusórias. Logo, de acordo com Žižek e com Lacan, a verdade psicanalítica reside no confronto com o vazio. De outro lado, para Badiou, a verdade está no longo trabalho de fidelidade e de forçamento de uma nova lei para a situação (BADIOU, 1988).

As consequências políticas da divergência entre Badiou e Žižek ficam mais claras, se atentarmos para o caso da desintegração do Socialismo do Leste Europeu. Para Badiou, não houve aí um Evento, pois, após o fim do Socialismo, não foi instaurada uma nova lógica. Žižek, por seu turno, argumenta que o movimento popular que disse não ao regime comunista, em nome de uma solidariedade autêntica, produziu um verdadeiro ato. Ocorre que o ato implica riscos, inclusive o de que nada realmente novo seja instaurado depois dele (foi justamente isso que aconteceu no Leste Europeu).

Žižek enxerga hoje um potencial para o surgimento de uma nova forma de comunismo como resultado da pandemia de Covid-19 e, por essa razão, tem sido objeto de recorrentes chacotas de Badiou. Segundo o esloveno, o vírus realiza um tipo de negação, é uma força que irá quebrar o mundo tal como conhecemos:

O vírus irá destruir os alicerces de nossas vidas, causando não apenas um enorme sofrimento, mas também uma devastação econômica possivelmente pior que a Grande Recessão. Não há retorno ao normal, o novo normal terá de ser construído das ruinas de nossas vidas antigas ou nos encontraremos em um novo barbarismo cujos sinais já são claramente discerníveis. (ŽIŽEK, 2020, p. 12). 
Se aceitarmos o argumento de Žižek, concluiremos que é falsa a oposição formulada por Badiou entre ordem do Ser e do Evento. O sujeito está inscrito na mesma estrutura ontológica do universo, ele é paradoxo de um elemento particular que sustenta o universal (ŽIŽEK, 2000, p. 161). O filósofo esloveno, portanto, continua a seguir Lacan e também a dialética hegeliana:

A questão, contudo, permanece: o pensamento hegeliano acolhe uma abertura para o futuro ou o fechamento do seu Sistema a descarta a priori? Apesar de aparências enganosas, devemos responder: sim, o pensamento de Hegel é aberto para o futuro, mas precisamente em razão de seu fechamento. Em outras palavras, a abertura de Hegel para o futuro é negativa, é articulada por suas afirmaçôes negativas/limitadoras como "não se pode saltar para fora do seu próprio tempo" da Filosofia do Direito. A impossibilidade de se apropriar diretamente do futuro está baseada no fato de que a retroatividade faz com que o futuro seja a priori imprevisível: não podemos subir nos nossos próprios ombros e nos observar como objetivamente participamos da textura da história, pois tal textura é uma vez e de novo retroativamente reorganizada. (ŽIŽEK, 2020, p. 12).

Em termos lacanianos, nossas ações não apenas dependem do grande Outro como também o transformam. Assim, "[...] a consciência de que um ato retroativamente cria suas condiçôes de possibilidade não deve nos fazer temer o acolhimento daquilo de que, antes do ato aparece apenas como impossível." (ŽIŽEK, 2012, p. 188). Fidelidade ao Real tem aqui o sentido muito diferente daquele defendido por Badiou: significa arriscar-se a agir sem qualquer amparo.

Se quisermos levar adiante a perspectiva lacaniana mobilizada por Žižek para pensar as revoluçóes, resta, contudo, refletir sobre uma questão. Lacan ancora sua teoria na clínica; nesse setting, percebe os efeitos transformadores do ato analítico. De outra parte, o esloveno recorre à psicanálise para formular uma espécie de constelação conceitual, a qual seria suficiente para sustentar suas constataçóes sobre o cinema de Tarantino, as revoluçôes do Leste Europeu e a pandemia de Covid-19. Não faltaria ao filósofo, por conseguinte, encontrar alguma forma mais consistente de ancoragem concreta (como a foi clínica para Lacan) que lhe permita compreender com mais clareza como ocorre um ato? Decerto Žižek fornece diversos exemplos de atos políticos (como o caso do Leste Europeu); podemos, no entanto, indagar: os exemplos do filósofo são realmente capazes de objetar (de algum modo resistir) aos seus conceitos 
(como a clínica fez, ao longo da história da psicanálise freudiana e lacaniana)? Seriam os exemplos selecionados com o propósito de somente confirmar sua teoria?

Cabe aqui lembrar o debate com outra leitora heterodoxa de Lacan. No livro Contingência, Hegemonia e Universalidade, o esloveno expóe, com razão, os aspectos mais problemáticos da leitura da psicanálise feita por Judith Butler. Ocorre que o contra-argumento da filósofa norte-americana atinge o cerne das dificuldades de Žižek. Ela não duvida de que estruturas atuam subrepticiamente na constituição da vida social e sabe que o que não é assimilável pela linguagem produz efeitos; ainda assim, insiste na importância de se aproximar de práticas de movimentos sociais e outras coalizões políticas e insiste em tentar encontrar nelas a ancoragem que talvez falte ao esloveno. Butler (2000b, p. 169) se esforça para reformular conceitos filosóficos e psicanalíticos a partir da ação de atores sociais; sobre estes últimos, afirma: "[...] não acredito que o intelectual pode estar em uma distância radical.”(ŽIŽEK; BUTLER; LACLAU, 2000, p 169). Tal preocupação se assemelha a algo que Lacan certa vez chamou de formação de alianças.

Ainda que a leitura da psicanálise realizada pela norte-americana apresente, de fato, dificuldades (como Žižek mostra), parece-me que o seu convite a uma reconstrução da psicanálise, a partir de práticas políticas, precisa ser levado a sério. Gostaria de me aprofundar nessa reflexão em futuros trabalhos.

FISCHER, M. P. Event or act? On Žižek's critiques of Badiou. Trans/form/ação, Marília, v. 44, n. 3, p. 317-336, Jul./Set., 2021.

\begin{abstract}
Alain Badiou's concept of Event and contraposes it to Slavoj Žižek's reformulations of Lacanian notion of act. It exams the central works in which the French philosopher reconstructs Lacanian concepts based in ingenious associations with Espinosa, Aeschylus and militant texts of Marx. Badiou writes about a non-dialectical division between Being and Event. Žižek, who remains faithful to Lacan and also Hegel, argues that there is unity instead of two separated dimensions. According to the Slovenian, a political act does not immediately establishes a new beginning, it just clears the way for it. Saying "no": would it the genuine revolutionary act?
\end{abstract}

Keywords: Event. Act. Revolutions. Psychoanalysis. 


\section{REFERÊNCIAS}

BADIOU, A. Theori du Sujet. Paris: Seuil, 1982.

BADIOU, A. L'Être et L'Événement. Paris: Seuil, 1988.

BADIOU, A. Conditions. Paris: Seuil, 1992.

BADIOU, A. Ética - um Ensaio Sobre a Consciência do Mal. Rio de Janeiro: Relume Dumará, 1995a.

BADIOU, A. São Paulo: A Fundação do Universalismo. São Paulo: Boitempo, 1995b.

BADIOU, A. Compêndio de Metapolítica. Lisboa: Piaget, 1999.

BADIOU, A. Logique des Mundes: L'Être et L'Événement 2. Paris: Seuil, 2006.

BADIOU, A.; ŽIŽEK, S. Philosophy in the Present. Cambridge: Polity, 2009.

BADIOU, A. Louis Althusser: le (re)commencement du matérialisme historique. In: BADIOU, A. L'aventure de la philosphie française: depuis les années 1960. Paris: La Fabrique, 2012.

BADIOU, A. et al. Sopa de Wuhan: Pensamiento Contemporaneo en Tiempos de Pandemias. ASPO, 2020.

BOSTEELS, B. Alain Badiou's Theory of the Subject: Part I. The Recommencement of Dialectical Materialism? Pli (Warwick Journal of Philosophy), v. 12, p. 200-229, 2001.

BOSTEELS, B. Translater's Introduction. In: BADIOU, A. Theory of the Subject. Londres: Continuum, 2009.

FREUD, S. Além do Princípio do Prazer (1920). In: FREUD, S. Obras Completas, v. 14. São Paulo: Companhia das Letras, 2010a.

FREUD, S. O Inquietante (1919). In: FREUD, S. Obras Completas, v. 14. São Paulo: Companhia das Letras, 2010 b.

LACAN, J. O Seminário. Livro 11: os quatro conceitos fundamentais da psicanálise. Rio de Janeiro: Jorge Zahar, 1988.

LACAN, J. O Seminário. Livro 11: os quatro conceitos fundamentais da psicanálise. Rio de Janeiro: Jorge Zahar, 1988.

LACAN, J. Ato psicanalítico. In: LACAN, J. Outros Escritos. Rio de Janeiro: Jorge Zahar, 2003a.

LACAN, J. Proposição de 9 de outubro de 1967 sobre o psicanalista da Escola. In:

LACAN, Jacques. Outros escritos. Rio de Janeiro: Jorge Zahar, 2003 b.

LACAN, J. O Seminário. Livro 10: a Angústia. Rio de Janeiro: Jorge Zahar, 2005. 
LACAN, J. (1967-1968). O Seminário. Livro 15: O ato psicanalítico (não publicado). LAPLANCHE, J. Vida e Morte em Psicanálise. Porto Alegre: Artes Médicas, 1985. MILLER, J-A. La Suture (éléments de la logique du signifiant). Cahiérs pour l'Analyse, p. 38-49, 1966.

SAFATLE, V. Grande Hotel Abismo: Por uma Reconstrução da Teoria do Reconhecimento. São Paulo: Martins Fontes, 2012.

SAFATLE, V. Circuito dos Afetos: Corpos políticos, Desamparo, Fim do Indivíduo. São Paulo: Cosac Naify, 2015.

SPINOZA, B. Ética. Belo Horizonte: Autêntica, 2009.

ŽIŽEK, S. Ticklish Subject: The Absent Centre of Political Ontology. Nova Iorque/ Londres: Verso, 2000.

ŽIŽEK, S. For they not know what they do: enjoyment as a political factor. Nova Iorque/Londres: Verso, 2008.

ŽIŽEK, S. Less Than Nothing: Hegel and the shadow of dialectical materialism. New York, London: Verso, 2012.

ŽIŽEK, S. Pandemic: Covid-19 Shakes de World. New York \& London: OR Books, 2020.

ŽIŽEK, S.; BUTLER, J.; LACLAU, E. Contingency, Hegemony, Universality:

Contemporary Dialogues on the Left. New York, London: Verso, 2000.

Recebido: 19/9/2020

Aceito: $07 / 4 / 2021$ 